Volume 93 Number 884 December 2011

\title{
INTERNATIONAL REVIEW of the Red Cross
}

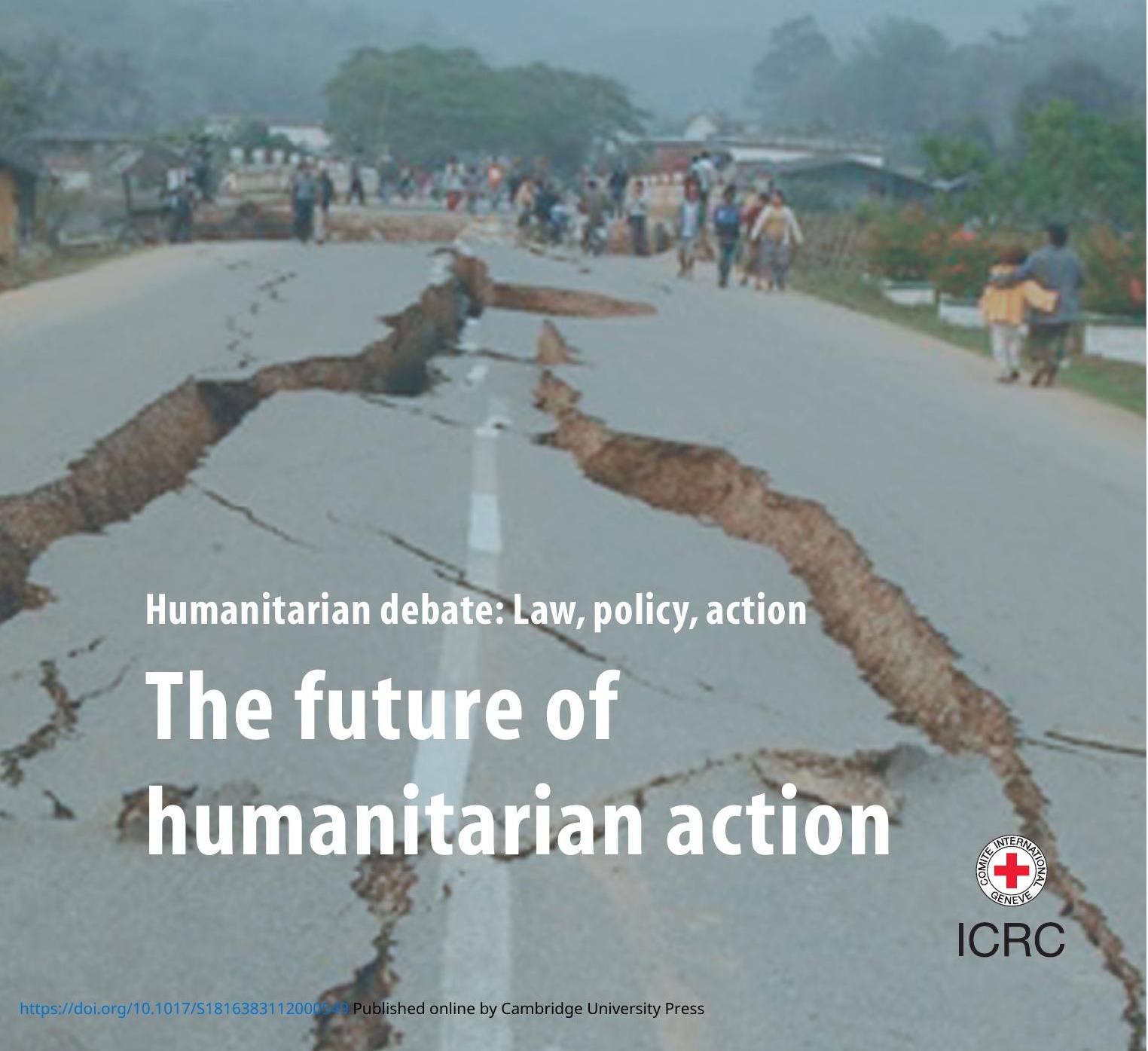


Editor-in-Chief: Vincent Bernard Editorial assistants: Mariya Nikolova and Michael Siegrist Publication assistant: Claire Franc Abbas

International Review of the Red Cross 19, Avenue de la Paix CH - 1202 Geneva $\mathrm{t}+41227346001$ f +41227332057 e-mail: review@icrc.org

Editor-in-Chief

Vincent Bernard ICRC

Editorial Board

Rashid Hamad Al Anezi

Kuwait University, Kuwait

Annette Becker

Université de Paris-Ouest Nanterre La Défense, France

Françoise Bouchet-Saulnier Médecins sans Frontières, Paris, France

Alain Délétroz

International Crisis Group, Brussels, Belgium

Helen Durham

Australian Red Cross, Melbourne, Australia

Mykola M. Gnatovskyy

Kyiv National Taras Shevchenko

University, Ukraine

Bing Bing Jia

Tsinghua University, Beijing, China

Abdul Aziz Kébé

Cheikh Anta Diop University, Dakar, Senegal

Elizabeth Salmón

Pontificia Universidad Católica del Perú, Lima, Peru

Marco Sassòli,

University of Geneva, Switzerland

Yuval Shany

Hebrew University, Jerusalem, Israel

Hugo Slim

University of Oxford, UK

Gary D. Solis

Georgetown University, Washington DC, USA

Nandini Sundar

Delhi University, New Delhi, India

Fiona Terry

Independent researcher on humanitarian action, Australia

Peter Walker

Feinstein International Center,

Tufts University, Boston, USA 


\section{NTERNATIONAL REVIEW of the Red Cross}

Humanitarian debate: Law, policy, action

\section{The future of} humanitarian action 


\section{CONTENTS}

\section{Editorial}

Vincent Bernard, Editor-in-Chief

\section{Discussion}

What are the future challenges for humanitarian action?

Dr. Kristalina Georgieva, European Commissioner responsible for International Cooperation, Humanitarian Aid and Crisis Response, and Dr. Jakob Kellenberger, President of the International Committee of the Red Cross

\section{Articles}

New threats, new responses

915 Megatrends and the future of humanitarian action Elizabeth Ferris

939 Planning from the future: an emerging agenda Randolph C. Kent

965 The future of humanitarian action: an ICRC perspective Claudia McGoldrick

\section{Humanitarian principles put at test}

993 The legal framework of humanitarian access in armed conflict Felix Schwendimann

1009 What Americans think of International Humanitarian Law Brad A. Gutierrez, Sarah DeCristofaro and Michael Woods 
1035 Using humanitarian aid to 'win hearts and minds': a costly failure? Jamie A. Williamson

1063 The use of force to protect civilians and humanitarian action: the case of Lybia and beyond

Bruno Pommier

1085 Civil-military relations in natural disasters: a case study of the 2010 Pakistan floods

Ajay Madiwale and Kudrat Virk

\section{In folio}

'Yo lo vi'. Goya witnessing the disasters of war: an appeal to the sentiment of humanity

Paul Bouvier

\section{Changing actors and evolving practice}

1135 Opportunity knocks: why non-Western donors enter humanitarianism and how to make the best of it

Andrea Binder and Claudia Meier

1151 What future role for local organizations? A reflection on the need for humanitarian capacity-building

François Audet

1165 Humanitarian organizations involved in protection activities: a story of soul-searching and professionalization

Pierre Gentile

1193 Fit for purpose: the role of modern professionalism in evolving the humanitarian endeavour

Peter Walker and Catherine Russ 
1211 The emerging concept of humanitarian diplomacy: identification of a community of practice and prospects for international recognition

Philippe Régnier

1239 New information technologies and their impact on the humanitarian sector

Patrick Meier

\section{Obituary}

1265 Tribute to Judge Antonio Cassese (1937-2011)

Books and articles

1267 New Edition: How does Law Protect in War?

1268 Recent acquisitions of the Library and Public Archives, ICRC 